\title{
ASPEK RITUAL DAN SOSIAL DALAM TIPOLOGI PERILAKU KEBERAGAMAAN MASYARAKAT
}

\author{
Yudi Ariyanto \\ STIT Makhdum Ibrahim Tuban \\ yudiarianto@stitmatuban.ac.id \\ Rinwanto \\ STIT Makhdum Ibrahim Tuban
}

\begin{abstract}
Abstrak
Agama Islam merupakan agama yang $k \bar{a} f f a h$, tidak hanya mengatur hubungan manusia dengan Tuhannya (vertical), amalan amalan yang berhubugan dengan ibadah atau aspek ritual, tetapi juga mengatur pola hubungan antar sesama manusia (Horizontal), atau dikenal dengan istilah muamalah (aspek social) yang menekankan sikap toleran terhadap sesama makhluk, terpenuhinya aspek mu'amalah sangat penting bukan hanya sebagai pelengkap unsur ubudiyah, akan tetapi sebagai manifestasi dari kebenaraan ritual ubudiyyah. Realitas perjalan kehidupan masyarakat, dalam tataran perjalanannya sering terjadi ketidak seimbangan antara aspek ritual dan sosial, ritual ubudiyyah bagus akan tetapi aspek sosial (mu'amalah)nya kurang bagus ataupun sebaliknya, yang akan berimplikasi pada kesenjangan hidup, kesenjangan antara aspek lahir dan batin.

Problem ini yang menjadi objek kajian penulis yaitu: apa pengertian ibadah dan mu'amalah?, bagaimana hubungan ibadah dan mu'amalah?, bagaimana perbedaan aspek ibadah dan mu'amalah?, bagaimana purifikasi dalam ibadah dan modernisasi dalam sosial berdasarkan prinsip aspek ibadah dan mu'amalah?, dan bagaimana peranan nalar dalam bidang ibadah dan bidang sosial.

Berdasarkan hasil kajian, penulis menyimpulkan, ibadah mengatur hubungan manusia dengan Tuhannya sedang muamalah adalah transaksi pola hubungan antar sesama manusia. Hubungan ibadah dan muamalah adalah akomodatif, aspek ibadah mengutamakan kepentingan individu dalam ibadah kepada Tuhannya. Adapun aspek muamalah mengutamakan kepentingan sosial, modernisasi dalam mu'amalah diizinkan oleh shari'ah Islam, selama tidak bertentangan dengan prinsip dan jiwa shari'ah Islam itu sendiri. Peran nalar dalam bidang ibadah tidak bisa ikut andil berperan karena dalam ibadah terkandung nilai-nilai ta'abbudi/ ghairu ma'qulati alma'nairasional, sedangkan bidang sosial (mu'amalah) bersifat ta'aquly/ ma'qulati alma'na rasional.

Kedua aspek antara aspek ritual dan sosial tersebut, agama Islam sangat memerhatikan kesejahteraan manusia di dunia maupun di akhirat. Islam mengandung tuntunan untuk menjalani kehidupan secara proporsional, yang apabila manusia mematuhi rambu rambu yang diperintah dan dilarang oleh syara' maka akan memperoleh kehidupan yang layak di dunia dan di akhirat.
\end{abstract}

Kata Kunci: Ritual (Ubudiyah), Sosial (Mu'amalah)

Tadris, Volume 13/No.1/Tahun 2019 


\section{PENDAHULUAN}

Agama Islam merupakan agama yang käffah, tidak hanya mengatur hubungan manusia dengan Tuhannya (vertical) akan tetapi juga mengatur pola hubungan antar sesama manusia (Horizontal), dari kedua aspek tersebut agama Islam sangat memperhatikan kesejahteraan manusia di dunia maupun di akhirat kelak. Islam mengandung tuntunan untuk menjalani kehidupan secara proporsional yang apabila manusia mematuhi rambu rambu yang di perintah dan dilarang oleh syara' maka akan memperoleh kehidupan yang layak di dunia dan di akhirat.

Apabila kita renungkan, ada dua pemilahan pokok dalam kajian keislaman, pertama, aspek ibadah. Dan kedua, aspek mu'amalah. Aspek ibadah bertendensi pada aturan-aturan ilahiyah yang mengatur hubungan antara hamba dengan Tuhannya. Sedang aspek mu'amalah menitikbratkan pada tatanan hidup antar sesama manusia, dimana jika kedua aspek ini terpenuhi akan terbentuk keseimbangan dalam hidup seseorang.

Aspek ibadah lebih bersifat stagnan, sehingga terkesan jumud dan kaku, berangkat dari sini banyak kita jumpai bentuk-bentuk ibadah yang kadangkala tidak dapat dinalar tentang hikmah yang terkandung di dalamya. Sedang dalam aspek mu'amalah lebih bersifat dinamis dan fleksibel, dapat mengikuti dan mengiringi perubahan budaya dan zaman yang semakin maju. Oleh karna itu dalam artikel/makalah ini, penulis akan mencoba menguraikan hal-hal yang berkenaan dengan aspek ibadah dan mu'amalah.

\section{PEMBAHASAN}

\section{Pengertian hukum Islam: Ibadah dan Mu'amalah}

Ibadah secara bahasa (etimologi) berarti merendahkan diri serta tunduk. (Pusat Lembaga Kajian Penelitian, 1966 : 110) Sedangkan menurut syara' (terminologi), ibadah mempunyai banyak definisi, tetapi makna yang paling jelas adalah, sebutan yang mencakup seluruh apa yang dicintai dan diridhai Allah Azza wa Jalla, baik berupa ucapan atau perbuatan, yang zhahir maupun yang bathin. (Pusat Lembaga Kajian Penelitian, 1966 : 110)

Ibadah inilah yang menjadi tujuan penciptaan manusia. sebagaimana ditegaskan dalam Q.S. Al- Dzaariyaat: 56-58 bahwa Allah SWT memberitahukan hikmah penciptaan jin dan manusia adalah agar mereka melaksanakan ibadah kepada Allah SWT. Allah Maha Kaya, tidak membutuhkan ibadah mereka, akan tetapi mereka yang membutukan-Nya. Karena ketergantungan mereka kepada Allah SWT. maka mereka menyembah-Nya sesuai aturan syari'at-Nya. Maka siapa yang menolak ibadah kepada Allah SWT. ia adalah sombong. Siapa 
yang menyembah-Nya tetapi dengan selain apa yang disyari'atkan maka ia adalah mubtadi (pelaku bid'ah). Dan siapa yang hanya menyembah-Nya dan dengan syari'at-Nya, maka dia adalah mukmin muwahhid (yang mengesakan Allah).

Ibadah itu terbagi menjadi ibadah hati, lisan dan anggota badan. Rasa khauf (takut), raja' (mengharap), mahabbah (cinta), tawakkal (ketergantungan), raghbah (senang), dan rahbah (takut) adalah qalbiyah (yang berkaitan dengan hati). Sedangkan shalat, zakat, haji dan jihad adalah ibadah badaniyah qalbiyah (fisik dan hati).

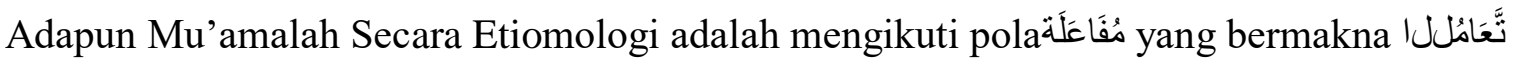
bergaul/saling beramal. Menurut Al-kasani, (1982:185), "Secara Terminologi Mu'amalah adalah ungkapan dari suatu akad atas perbuatan dengan sebagian pengeluaran disertai syarat jawaz". Atau, sebuah istilah yang digunakan untuk permasalahan selain ibadah. Dengan definisi tersebut Mu'amalah mencakup pengertian yang lebih umum tidak hanya dalam transaksi jual beli, sewa menyewa ataupun bentuk transaksi lainnya, melainkan segala bentuk hubungan antar manusia juga merupakan aspek mu'amalah, inilah yang dikehendaki dari aspek mu'amalah dalam pengertian luasnya.

\section{Hubungan Ibadah dan Mu'amalah.}

Ibadah dan mu'amalah merupakan dua aspek yang saling berkaitan, yang tidak mungkin dipisahkan antara satu sama lain, jika boleh diandaikan, kedudukan ibadah seperti halnya wujud ruh dalam jasad, sedang posisi mu'amalah layaknya jasad pada diri manusia, baik aspek ibadah maupun mu'amalah keduanya merupakan satu kesatuan yang mempunyai andil besar dalam membentuk keseimbangan hidup manusia.

Ibadah merupakan kebutuhan rohani seseorang, jika kebutuhannya tidak terpenuhi akan menyebabkan ketidak seimbangan dalam kehidupan, kebutuhan rohani seperti shalat, puasa, zakat dan amalan-amalan 'ubudiyah yang lain, secara tidak langsung akan mendatangkan ketenangan dan kedamaian dalam jiwa, tentu setiap manusia selalu butuh akan rasa damai dan tentram, jika hal ini tidak tercapai tentu akan berimplikasi pada kesenjangan hidup, kesanjangan antara aspek lahir dan batin yang selanjutnya akan menggiring pada tataran apatis terhadap sikap bermasyarakat.

Tidak cukup hanya terpenuhinya ritme ibadah dalam diri manusia, melainkan juga dituntut pada terpenuhinya aspek sosial, aspek sosial yang menekankan sikap toleran terhadap sesama makhluk, dalam arti aspek mu'amalah mengatur bagaimana pentingnya berbuat baik dan 
menempatkan diri pada posisi semestinya dalam berinteraksi dengan sesama. Terpenuhinya aspek mu'amalah menjadi sangat penting bukan hanya sebagai pelengkap unsur ubudiyah, akan tetapi karena ia merupakan manifestasi dari kebenaraan ritual ubudiyyah, nilai-nilai yang terserap dari ritual ibadah selanjutnya akan bertransformasi dan bersinergi dengan aktifitas mu'amalah seseorang, yang tercermin dalam sikap yang luhur serta budi pekerti yang baik.

Berbicara mengenai ubudiyyah bukan semata-mata berbicara tentang keyakinan, prinsip hidup dan kebutuhan spiritual, berbicara 'ubudiyah berarti membahas lebih jauh ke depan mengenai kepercayaan setelah mati, tentang surga, neraka dan kehidupan yang kekal, dengan begitu aspek yang dibicarakan oleh ubudiyyah selalu terkait erat dengan aspek mu'amalah, perilaku yang menyimpang dalam kegiatan mu'amalah selalu diperingatkan dengan ancamanancaman dosa yang akan didapat kelak. Ancaman-ancaman tersebut selalu berkaitan dengan Iman/keyakinan yang dapat dijumpai dalam aspek ubudiyah.

\section{Perbedaan asas antara aspek ibadah dan aspek mu'amalah}

Gambaran tentang shari'ah Islam dalam menjawab segala persoalan modern dapat diketahui dengan mengemukakan beberapa prinsip shari'ah Islam mengenai tatanan hidup secara vertical (antara manusia dengan Tuhannya) dan secara horizontal (antara sesama manusia). Kebanyakan ahli fiqh menetapkan kaidah bahwa hukum asal segala sesuatu dalam bidang material dan hubungan antara sesama manusia (mu'amalah) adalah boleh, kecuali apabila ada dalil yang menunjukkan bahwa sesuatu itu dilarang. (Djamil, 1997:40)

Kaidah di atas berlawanan dengan kaidah hukum dalam bidang ibadah. Dalam bidang ibadah, shari'ah Islam menetapkan sendiri garis-garisnya. Di sini dikemukakan nash-nash yang tidak dapat ditafsirkan lain, sehingga terjaga dari kesimpangsiuran.(Ash-Shiddieqy, 1982:23) Dalam bidang yang disebut terakhir ini, terdapat kaidah bahwa ibadah tidak dapat dilakukan kecuali apabila ada dalil yang menunjukkan bahwa sesuatu itu telah diperintahkan oleh Allah dan atau dicontohkan oleh Rasul.

Al-Shatibi mencoba mengembangkan lebih lanjut prinsip-prinsip di atas, beliau sebagaimana ahli fiqh lainnya membedakan materi hukum Islam menjadi dua bagian. Bagian prtama materi hukum Islam yang menyangkut ibadah dan kedua, materi hukum Islam yang menyangkut mu'amalah ('adat). Ia secara filosofis telah merumusan kaidah sebagai berikut: (Djamil, 1997:41) 


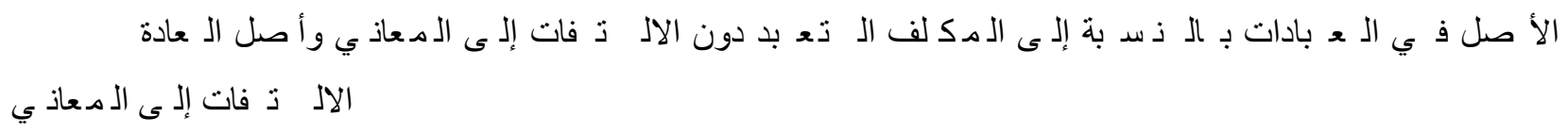

Prinsip dalam persoalan ibadat bagi mukalaf adalah ta'abbud tanpa perlu melihat kepada nilai atau hikmah, sedangkan prinsip dalam persoalan adat (Mu'amalah) adalah melihat kepada nilai atau hikmah.

Perlu segera ditambahkan bahwa al-Shatibi sendiri mengakui adanya beberapa bentuk Mu'amalah yang mempunyai nilai ta'abbudi. Kelihatannya yang dimaksud ta'abbudi di sini adalah hukum yang diterapkan berdasarkan dalil-dalil yang terperinci.(Al-Shatibi 1341:211) Adapun Maksud dari bidang ibadah dan mu'amalah adalah sebagai berikut:

\section{Mengutamakan Kepentingan Individu Dalam Bidang Ibadah}

Shalat yang kita lakukan, bukanlah hanya merupakan gerak olah raga yang kita lakukan 5 kali sehari semalam. Tapi maksud shalat yang lebih esensial adalah untuk memperbarui kepercayaan dan keimanan kepada Allah dan menghidupkan prinsip-prinsip Islam yaitu bersifat amanah berlaku benar, menepati janji dan mengutamakan orang lain. Esensi puasa bukan hanya menahan diri dari haus dan lapar, tetapi lebih dari itu puasa menunjukkan kemuliaan perangai, mendidik jiwa, membiasakan manusia menagalahkan hawa nafsu dan menegendalikan kecenderungan-kecenderungannya, supaya sanggup mengatasi dorongan hati kepada perbuatan salah, dan melatih kesabaran.(As-Sidqy : 408) Begitu pula ibadah-ibadah dalam Islam lainnya mempunyai hikmah dan makna tersendiri dan mempunyai pengaruh terhadap rohani yang nantinya akan mempengaruhi fisiknya juga.

Dari penjelasan diatas dapat kita pahami bahwa manfaat ibadah kembalinya ke individu muslim itu sendiri bukan kepada orang lain. Maka dari itu, perintah ibadah ditujukan kepada masing-masing individu manusia bukan kolektif. Adapun ibadah yang dilakukan secara kolektif tidak diperintahkan sebagai hal yang wajib melainkan sunnah dan mempunyai nilai plus dalam ibadah itu sendiri. Maka dapat dikatakan disini bahwa ibadah adalah tanggung jawab setiap individu manusia. salah satu kaidah fiqh menyatakan "mengutamakan orang lain dalam hal فbadah hukumnya makruh” (راثالا gnaro adapek hadabi nakhapmilem anerak في الـ ع بادة مكروه lain merupakan tindakan yang kurang adab/kurang sopan kepada Allah.

Makna ibadah itu sendiri, yang masuk dalam bidang irasional yang tidak dibuka pintu jitihad di dalamnya. Sehingga manusia sebagai hambaNya diharuskan tunduk (khudhu') dalam 
melaksanakan perintahNya. Dan karena hakikat penciptaan manusia adalah untuk beribadah kepada Nya, sebagaimana firman Allah dalam surah al-Dzariyat 56

2. Mengutamakan Kepentingan Sosial Dalam Bidang Mu'amalah

Segala ibadah dalam hukum Islam merupakan washilah, bukan ghayah. Karena itu Islam bukanlah agama rabbanah, bukan pula agama yang melebih-lebihkan dalam masalah mengerjakan ibadah. Bahkan Rasulullah mencontohkan ketika mengerjakan ibadah manusia juga tidak boleh melupakan kebutuhan fisiknya. Sabda Rasulullah: ( Al-Humaidi)

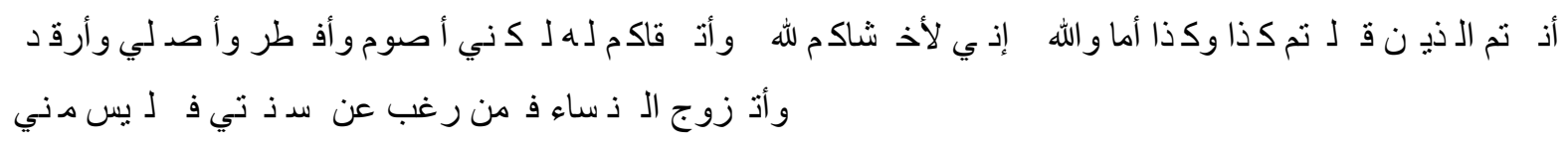

Kamukah yang mengatakan begini, dan begitu, ketahuilah demi Allah, aku adalah orang yang paling takut diantara kamu kepada Allah dan paling taqwa kepadaNya, namun demikian aku berpuasa, aku berbuka, aku shalat malam, aku tidur dan mengawini wanita. Karena itu orang yang membenci sunnahku, maka ia bukanlah dari golonganku.

Selain manusia memerlukan ibadah untuk memenuhi kebutuhan rohaninya, manusia juga memerlukan masyarakat untuk memenuhi kebutuhan sosialnya. Manusia tidak dapat hidup sendiri, dia butuh hidup bermasyarakat. Hukum Islam mengakui hal tersebut, sehingga tidak hanya mengatur tentang ibadah yang merupakan hubungan vertikalnya dengan tuhan, hukum Islam juga mengatur tentang ibadah horisontal yang mengatur hubungannya antar sesama manusia. dalam hal ini Islam bahkan mengajak manusia untuk membangun lingkungan dengan sebaik-baiknya. (As-Sidqy:409)

Kembali kepada karakteristik hukum Islam yang menjadikan manusia sebagai tujuan akhirnya, banyak ayat-ayat al-qur'an dan hadist yang menunjukkan dan menerangkan kepada kita bahwa tujuan Islam dari mendirikan ibadat adalah bukan semata-mata hanya untuk ibadah kepada Tuhan saja. Tapi itu semua sebenarnya hanya jalan (washilah) saja untuk mencapai maksud Allah yang menautkan segala macam ibadah dengan kebutuhan manusia. Bahkan hukum Islam menetapkan apabila nilai-nilai perbuatan manusia tidak kembali kepada kemanfaatan dan kebaikan atau tidak berfaedah bagi masayarakat, maka tidak ada kebaikan dalam ibadah-ibadah yang sudah dilaksanakannya. (As-Sidqy:408) Misalnya, jika seseorang hanya rajin beribadah, dia selalu mengerjakan shalat-sunnah, puasa-puasa sunnah, dan ibadah-ibadah yang lainnya, tetapi tidak pernah berbuat baik dalam bidang sosial kemasyarakatan, maka sebenarnya ibadahnya 
tidak berarti. Dalam hal ini dapat kita pahami bahwa Allah selalu mengaitkan segala sesuatu terhadap perbuatan manusia. Karena memang tujuan hukum Islam sendiri adalah untuk menjaga manusia.

Jika dalam kaidah fiqh mengutamakan orang lain dalam hal ibadah makruh, maka dalam

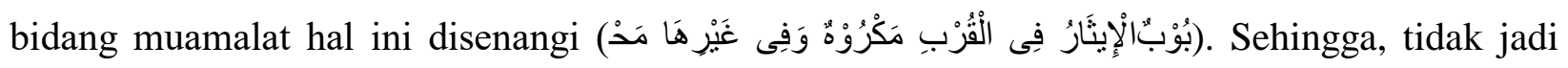
masalah jika mendahulukan orang lain dalam hal duniawi atau masalah sosial di masyarakat. Dari kaidah ini dapat kita pahami bahwa manusia, selain menjadi 'Ibadullah disatu sisi, di sisi lain ia juga merupakan khalifatullah fil ardhi, sehingga selain menjalankan kewajibannya terhadap penciptaNya dia juga harus menjalankan kewajibannya terhadap sesama manusia, yaitu menjadi mahluk sosial dalam hal mu'amalah.

Dari segi bidang hukum Islam, mu'amalah adalah ibadah rasional yang dibukakan pintu ijtihad didalamnya, dan diangkat derajat akal untuk berpikir demi kemaslahatan manusia sendiri. Sehingga dalam hal mu'amalah hendaknya manusia dapat berkreasi dan mengembangkan dirinya untuk kepentingan sosial dan kemajuan manusia. Selalu mengutamakan kepentingan individual dalam hal ibadah dan mengutamakan kepentingan sosial dalam bidang muamalah, bukan hal yang bertentangan satu sama lainnya, melainkan dua hal yang saling melengkapi untuk mencapai suatu keseimbangan antara kepentingan individu dan masyarakat dalam hukum Islam. Sehingga untuk mencapai kemuliaan sebagai individu dan, masyarakat yang baik dihadapan Allah, seseorang harus bisa melaksankan dua hal ini dengan baik.

\section{Purifikasi dalam ibadah dan modernisasi dalam sosial}

Berdasarkan prinsip-prinsip atau asas di atas dapat dipahami bahwa modernisasi, dalam arti meliputi segala macam bentuk mu'amalah diizinkan oleh shari'ah Islam, selama tidak bertentangan dengan prinsip dan jiwa shari'ah Islam itu sendiri, menyadari bahwa kehidupan dan kebutuhan manusia itu selalu berkembang dan berubah, shari'ah Islam dalam bidang mu'amalah, pada umumnya hanya mengatur dan menetapkan dasar-dasar hukum secara Umum, sedangkan perinciannya diserahkan kepada umat Islam, di mana pun mereka berada. Tentu perincian itu tidak menyimpang apalagi bertentangan dengan prinsip dan jiwa shari'ah Islam.

Dapat dikatakan bahwa jiwa dan prinsip hukum Islam bersifat konstan, permanen, dan stabil, tidak berubah sepanjang masa, betapapun kemajuan peradaban manusia. Sementara itu, peristiwa hukum, teknis, dan cabang-cabangnya mengalami perubahan, berkembang sesuai dengan perkembangan zaman. Dengan tetap teguhnya dan prinsip hukum, dibarengi oleh terbuka 
lebarnya perubahan dan perkembangan cabang-cabangnya, terjaminlah modernisasi dan kemajuan ilmu pengetahuan secara leluasa, dengan tetap dilandasi oleh norma hukum yang ketat dan kuat, dengan adanya perubahan dan perkembangan masyarakat. Cabang-cabang hukum Islam dibidang mu'amalah semakin bertambah materi hukumnya, semakin banyak perbendaharaanya dan semakin sempurna pembahasannya. (Djamil, 1997:42)

Berbeda dengan bidang mu'amalah, hukum Islam dalam bidang ibadah maḥdah tidak terbuka kemungkinan adanya modernisasi, melainkan materinya harus berorientasi kepada nash al-qur'an dan hadis yang telah mengatur secara jelas tentang tata cara pelaksanaan ibadah tersebut, namun demikian, modernisasi dalam bidang sarana dan prasarana ibadah mungkin untuk dilakukan. (Djamil, 1997:42)

Dalam hal ini, Dr. Kaelany juga menjelaskan adanya dua prinsip yang perlu kita perhatikan, yaitu: Pertama: Manusia dilarang "menciptakan agama, termasuk system ibadah dan tata caranya, karena masalah agama dan ibadah adalah hak mutlak Allah dan para Rasul-Nya yang ditugasi menyampaikan agama itu kepada masyarakat. Maka menciptakan agama dan ibadah adalah bid'ah. Sedang setiap bid'ah adalah sesat.

Kedua: Adanya kebebasan dasar dalam menempuh hidup ini, yaitu hal-hal yang berkaitan dengan masalah mu'amalah, seperti pergaulan hidup dan kehidupan dalam masyarakat dan lingkungan, yang dikaruniakan Allah kepada umat manusia (Bani Adam) dengan batasan atau larangan tertentu yang harus dijaga. Sebaliknya melarang sesuatu yang tidak dilarang oleh Allah dan Rasul-Nya adalah bid'ah. (Kaelany, 2009:71)

Dalam menjalankan keseharian, penting bagi kita untuk mengingat dua prinsip di atas. Ibadah tidak dapat dilakukan dengan sekehendak hati kita karena semua ketentuan dan aturan telah ditetapkan dalam Al-Qur'an dan Sunnah, serta contoh dan tatacaranya telah diajarkan oleh Rasulullah SAW semasa hidupnya. Melakukan sesuatu dalam ibadah, yang tidak ada disebutkan dalam Al-Qur'an dan Sunnah berarti melakukan sesuatu yang tidak diperintahkan oleh Allah SWT, dan ini sungguh merupakan perbuatan yang sesat.

Namun dalam beberapa hal, tentu ada hal yang harus diperhatikan sesuai dengan perkembangan zaman. Di sini lah implikasi dari mu'amaah itu sendiri. Selama tidak ada larangan secara tegas di dalam Al-Qur'an dan Sunnah, hal yang dipertimbangkan itu boleh dilakukan. Hal ini telah diterangkan oleh Rasul dalam sabdanya yang sudah ditulis di atas. Sebagai contoh adalah dalam kehidupan sehari-hari, pada zaman hidupnya Rasulullah, masyarakat yang 
mengadakan perjalanan dari satu tempat ke tempat lain menggunakan binatang Unta sebagai kendaraan. Akan tetapi hal itu tidak mungkin sama dalam kehidupan zaman modern ini. Dan karenanya, menggunakan kendaraan bermotor diperbolehkan karena tidak ada larangan dari Allah dan Rasul-Nya (tidak tertera larangan yang tegas dalam Al-Qur'an dan Sunnah).

\section{Peranan Nalar dalam Bidang Ibadah dan Bidang Sosial}

Pada dasrnya ajaran Islam dapat dibedakan menjadi dua kelompok. Pertama, ajaran Islam yang bersifat absolut, universal, dan permanen, tidak berubah dan tidak dapat berubah. Termasuk kelompok ini adaah ajaran Islam yang tercantum dalam al-qur'an dan hadis mutawatir yang penunjukannya telah jelas (qaț'i al-dilālah), kedua, ajaran Islam yang bersifat relatif, tidak universal dan tidak permanen, melainkan dapat berubah dan diubah. Termasuk kelompok kedua ini adalah ajaran Islam yang dihasilkan melalui proses ijtihad. (Qardlawi, 1985:205) Kerangka berfikir ini sering muncul dikalangan ahli usul fikih dan pakar pembaharuan dalam Islam. Dikalangan ahli usul fikih dikenal dikotomi antara dalil qath'i dan dalil $d z h a n n i$, baik eksistensinya (wurud) maupun penunjukannya (dalalah). (Al-Zuhaili, 1969:605)

Para ahli hukum Islam sepakat mengenai penggunaan al-Qur'an sebagai sumber hukum yang utama dalam menentukan dan mengambil kesimpulan hukum. Mereka tidak meragukan eksistensi (wurud) al-qur'an dari ayat yang pertama sampai ayat yang terakhir diturunkan. Akan tetapi, ayat al-qur'an yang langsung menunjuk pada materi hukum sangat terbatas jumlahnya. Menurut Abdul Wahab Khallaf, bahwaayat-ayat hukum dalam bidang mu'amalah berkisar antara 230-250 ayat saja. (Khallaf, 1972:22) Sedangkan jumlah ayat al-qur'an seluruhnya lebih dari 6000 ayat. Jadi jumlah ayat hukum dalam al-qur'an sekitar 3-4 persen saja dari seluruh ayat alqur'an. Bahkan menurut Prof. Dr. H. Rasjidi, ayat-ayat al-qur'an yang mengandung hukum kurang lebih 200 ayat. Yakni sekitar 3 persen dari jumlah seluruhnya. (Rasjidi, 1980:22)

Dari jumlah ayat hukum yang sedikit itu pun para ahli hukum Islam berbeda pandanagn terhadap beberapa ayat yang penujukannya tidak tegas (dzhanni al-dilalah). Ayat-ayat seperti ini jumlahnya lebih banyak bila dibandingkan dengan ayat-ayat yang sudah tegas penunjukannya (qath'i al-dilalah). Melalui ayat-ayat dalam bentuk pertama, mereka mencoba membuat kesimpulan hukum atau penafsiran sesuai dengan pengetahuan kondisi dimana mereka hidup. Selama tidak keluar dari arti lafal. Sementara itu, kecenderungan mereka terhadap penggunaan hadis, sebagai sumber kedua hukum Islam, ternyata berbeda. Di antara mereka ada yang 
berpegang kepada teks hadis dan adapula yang lebih banyak menggunakan nalar ketimbang merujuk kepada hadis yang dianggapnya kurang kuat. Dalam sejarah hukum Islam kelompok pertama dikenaldengan ahlu al-hadis sedangkan kelompok yang kedua dikenal dengan sebutan ahlu al-ra'yi. (Ash-Shiddieqy, 1975:94) Oleh karena itu tidak heran kalau hasil ijtihad mereka berbeda.

Berbeda dengan al-Qur'an, keberadaan hadis seringkali dipermasalahkan. Hanya hadis yang sampaipada tingkat mutawatir sajalah yang eksistensinya sama dengan al-qur'an, karena itu tidak dipermasalahkan lagi. Sedangkan hadis yang di bawah peringkat mutawatir termasuk zhanni al-wurud, yang masih dapat dipertanyakan keberadaannya. Jumlah hadis yang termasuk kelompok terakhir ini jauh lebih banyak bila dibandingkan dengan hadis yang masuk kelompok pertama. Mengenai penunjukannya, keadaan hadis pun sama dengan al-qur'an. Adakalanya tegas penunjukannya dan adakalanya tidak tegas penujukannya.

Melalui celah-celah dari dalil yang zhanni baikwurud maupun dalalah-nya, para ahli hukum Islam berupaya untuk menemukan kesimpulan hukum. Oleh karena bersumber dari dalil zhanni, sudah dapat diduga bahwa kesimpulan hukumnya akan bersifa zhanni, dengan demikian, hasil ijtihad seseorang atau sekelompok orang lebih banyak yang bersifat relatif, tidak mutlak benar. Tidak ada alasan bagi umat Islam untuk menjadikan hasil ijtihad seseorang atau sekelompok orang sebagai kebenaran mutlak. Perbedaan pendapat dikalangan mereka justru mencerminkan kerelatifan pendapat tersebut, sejauh berupa hasil pemahaman ahli fikih, bisa jadi satu pendapat berbeda sama sekali dengan pendapat ahli fikih lainnya. (Djamil, 1997:45)

Ajaran Islam yang termasuk kelompok yang kedua, yang dzhanni al-dilalah yang relatif dan temporer itu telah memenuhi khazanah intelektual muslim dalam berbagai bidang, mulai dari bidang tafsir dan hadis sampai bidang filsafat, teologi dan hukum Islam. Dalam hubungan ini Harun Nasution secara ilustratif menyatakan, "kelompok ajaran Islam itu kecil di zaman nabi, lebih besar di khulafaur rasyidin, lebih banyak di zaman bani umayyah, lebih banyak lagi di zaman bani abbas, lebih banyak lagi di zaman bani utsman, begitulah selanjutnya berkembang. Akan tatapi al-qur'annya itu-itu juga" (Nasution dalam Yusuf, 1985:17). Pernyataan ini menunjukkan bahwa kemungkinan mengadakan perubahan dan pembaharuan ajaran Islam yang bersifat relatif, termasuk dalam bidang hukumnya, sangat besar. Atas dasar itu pula dapat dikatakan bahwa Islam sudah siap menghadapi persoalan modern.

Tadris, Volume 13/No.1/Tahun 2019 | 48 
Ada anggapan bahwa fikih Islam sebagai hasil ijtihad dari mujtahid terdahulu harus diterima sebagai kebenaran yang mutlak. Mempertahankan fikih Islam berarti sama dengan mempertahankan agama Islam secara keseluruhan. (Hosen, 1981:10) Padahal, sesuai dengan pengertian fikih itu sendiri, ilmu fikih bukanlah kebenaran yang mutlak, tidak semutlak ajaran transendental yang murni (wahyu). Belum lagi kalau persoalan yang dikaji merupakan persoalan yang sama sekali baru. Dalam hal ini kita tidak dapat bertumpu sepenuhnya pada pendapat ahli fikih terdahulu, tetapi harus mencoba menyelesaikannya sesuai dengan keadaan kita sekarang dengan tetap merujuk pada al-qur'an dan hadist.

Dalam bidang ibadah terkandung nilai-nilai ta'abbudil ghairu ma'qulati al-ma'na irasional. Artinya manusia tidak boleh beribadah kecuali dengan apa yang dishari'ahkan. Dalam bidang ini tidak ada pintu ijtihad bagi manusia. Sedangkan bidang mu'amalah bersifat ta'aquly/ ma'qulati al-ma'na rasional. Artinya, umat Islam dituntut untuk berijtihad guna membumikan ketentuan-ketentuan syari'ah tersebut.

Mencium Hajar Aswad ketika thawaf mengelilingi ka'bah merupakan ibadah yang irrasional, sampai Umar bin Khatab sendiri mengatakan, "kamu adalah batu biasa, kalaulah Rasul tidak menciummu, maka aku juga tidak akan mencimummu." Meski ada usaha untuk merasionalisasikannya, namun usaha tersebut sifatnya temporer, karena ia merupakan ijtihad manusia yang akan selalu berubah dengan perubahan masa. Aspek irrasional dalam bidang ibadah ini sebagian dari tujuannya adalah menunjukkan keterbatasan manusia. (Djamil, 1997:52).

\section{PENUTUP}

Berdasarkan hasil pembahasan makalah/artikel ini dapat disimpulkan dalam lima poin sebagai berikut: Pertama, Pengertian Ibadah dan Mu'amalah, ibadah berarti merendahkan diri serta tunduk, dalam istilah lain ibadah mengatur hubungan manusia dengan Tuhannya (vertical) sedang muamalah adalah transaksi pola hubungan atar sesama manusia (Horizontal).

Kedua, hubungan ibadah dan muamalah adalah akomodatif Ibadah merupakan kebutuhan rohani seseorang, akan mendatangkan ketenangan dan kedamaian dalam jiwa, sedangkan muamalah menekankan sikap toleran terhadap sesama makhluk, mengatur bagaimana pentingnya berbuat baik dan menempatkan diri pada posisi semestinya dalam berinteraksi dengan sesama. Terpenuhinya aspek mu'amalah menjadi sangat penting bukan hanya sebagai pelengkap unsur 
ubudiyah, akan tetapi karena ia merupakan manifestasi dari kebenaraan ritual ubudiyyah, nilainilai yang terserap dari ritual ibadah selanjutnya akan bertransformasi dan bersinergi dengan aktifitas mu'amalah seseorang, yang tercermin dalam sikap yang luhur serta budi pekerti yang baik.

Ketiga, perbedaan aspek ibadah dan muamalah adalah aspek ibadah mengutamakan kepentingan individu dalam bidang ibadah kepada Tuhannya, sedangkan aspek muamalah mengutamakan kepentingan sosial dalam bidang mu'amalah.

Keempat, purifikasi dalam ibadah dan modernisasi dalam sosial berdasarkan prinsip-prinsip atau asas aspek ibadah dan muamalah dapat dipahami bahwa modernisasi, dalam arti meliputi segala macam bentuk mu'amalah diizinkan oleh syari'ah Islam, selama tidak bertentangan dengan prinsip dan jiwa syari'ah Islam itu sendiri.

Kelima, peran nalar dalam bidang ibadah tidak bisa ikut andil berperan karna dalam ibadah terkandung nilai-nilai ta'abbudi/ ghairu ma'qulati al-ma'na irasional. Artinya manusia tidak boleh beribadah kecuali dengan apa yang disyari'ahkan dalam bidang ini tidak ada pintu ijtihad bagi manusia. Sedangkan bidang sosial (mu'amalah) bersifat ta'aquly/ ma'qulati al-ma'na rasional. Artinya, umat Islam dituntut untuk berijtihad guna membumikan ketentuan-ketentuan syari'ah tersebut sehingga dalam hal ini membuka peluang peran nalar sebagai pintu ijtihad.

\section{DAFTAR RUJUKAN}

Djamil, Fathurrahman. 1997. Filsafat Hukum Islam, Jakarta: Logos wacana ilmu Ibrahim, Hosen. 1981. Ukhuwah Islamiyah jangan menjadi retak dikarenakan masalah khilafiyah, makalah, Jakarta: perpustakaan IAIN syarif hidayatullah,

Kaelany HD.2009. Islam Agama Universal. Jakarta: Midada Rahma Press

Kasani, 'Alaudin (al). 1982. Bada'I al-sana'I Fi tartibi syara'i', Beirut: Dar al-kutub al-arabi Khallaf, Abdul Wahab. 1972. 'Ilm al-Ushul al-Fiqh, Jakarta: al-Majlis al a'la al-Indunisi li alDa'wah al-Islamiyah

Majallat al buhuts al Islamiyyah, Pusat lembaga kajian penelitian, keilmuan, fatwa, dakwah , Fiqh 'am, Maktabah Syamela Vol 76

Qardlawi, yusuf. 1985. al-Ijtihad fi al-shari'at al-Islamiyat ma' a nadzaratin tahliliyat fi alIjtihad al-Mu'ashir, Kuwait: Dar al-Qalam.

Rasjidi, M. 1980. keutamaan hukum Islam, Cet-2, Jakarta: Bulan bintang. Shatibi (Al). 1341 H. al-Muwafaqat fi Ushul al-ahkam, Beirut: Dar al-Fikr. Shiddieqy, Hasbie (al). Falsafah hukum Islam, Jakarta: Bulan Bintang, t. Th. Pengantar Hukum Islam, Jakarta: Bulan Bintang, 1975. Fakta keagungan syari'at Islam, cet. 2, Jakarta: Tinta mas, 1982.

Yusuf, M. Yunan, et, al. (Ed). 1985. Cita dan citra Muhammadiyah, Jakarta: Pustaka panji mas. Zuhaili, Wahbah (al).1969. al-Washith fi Ushul al-Fiqh, Dimsyaqi: al-Muthba'at al-'Ilmiyyat. 